\title{
Hubungan Berat Molekul dengan Ukuran Molekul Koloid yang Lazim Digunakan dalam Resusitasi Sindrom Syok Dengue
}

\author{
Kiki M.K. Samsi',2, Evelyn Phangkawira', Steve J. Yang ${ }^{3,4}$ \\ ${ }^{1}$ Bagian Ilmu Kesehatan Anak, Fakultas Kedokteran, Universitas Tarumanagara ,Jakarta \\ ${ }^{2}$ Bagian Ilmu Kesehatan Anak, Rumah Sakit Sumber Waras, Jakarta \\ ${ }^{3}$ Institute of Human Virology and Cancer Biology, Universitas Indonesia, Jakarta, \\ ${ }^{4}$ Center for Biomedical Engineering, Massachusetts Institute of Technology, Cambridge, Massachusetts.
}

\begin{abstract}
Latar belakang. Resusitasi cairan merupakan langkah penting dalam tata laksana sindrom syok dengue, namun sampai saat ini belum ada keseragaman jenis cairan yang digunakan. Pada umumnya klinisi di Indonesia memilih koloid dengan berat molekul (BM) lebih dari $100 \mathrm{kDa}$ untuk mendapatkan "efek sumbatan" (sealing effect) dengan asumsi bahwa semakin berat suatu molekul maka semakin besar ukuran molekul. Dalam uji klinis, perbedaan berat molekul koloid tidak menimbulkan perbedaan outcome sehingga menimbulkan pertanyaan apakah BM mencerminkan ukuran molekul.

Tujuan. Menilai apakah ukuran suatu molekul dapat ditentukan hanya dengan BM

Metode. Membandingkan bentuk dan ukuran antara empat jenis koloid dengan BM berbeda, dengan menggunakan alat dynamic light scattering.

Hasil: Urutan koloid dari BM terberat berturut-turut yaitu HES 200 kDa, HES 40 kDa, dextran 40kDa, dan gelatin $30 \mathrm{kDa}$. Berdasarkan koefisien difusi, didapatkan ukuran terbesar molekul koloid adalah gelatin $30 \mathrm{kDa}$ (lebih besar 100 x HES $200 \mathrm{kDa}$ )

Kesimpulan. Berat molekul tidak berhubungan langsung dengan ukuran molekul. Untuk mendapatkan "efek sumbatan" (sealing effect) perlu memperhitungkan bentuk dan ukuran molekul. (Sari Pediatri 2009;10(6):385-91).
\end{abstract}

Kata kunci: koloid, berat molekul, ukuran molekul

Alamat Korespondensi:

Dr. Kiki M.K Samsi., Sp A. Bagian Ilmu Kesehatan Anak, Rumah Sakit Sumber Waras, Jakarta. Fakultas Kedokteran, Universitas Tarumanagara, Jakarta.
I

nfeksi virus dengue menyebabkan penyakit endemis di sebagian negara Asia dan Amerika Selatan, serta berdampak besar terhadap jumlah korban maupun penurunan kesejahteraan di negara-negara tersebut. Salah satu manifestasi klinis berat akibat infeksi virus dengue adalah sindrom syok dengue atau dengue shock syndrome (DSS). Mortalitas 
kasus DSS antara 1\%-5\%, namun jika tidak dilakukan penanganan secara tepat, mortalitas dapat meningkat hingga lebih dari $40 \%{ }^{1}$

Pada pasien DSS terjadi peningkatan permeabilitas vaskular. Meskipun masih banyak perdebatan tentang patogenesis terjadinya kebocoran plasma, namun secara klinis dapat diterima bahwa penggantian cairan merupakan tindakan penting untuk menyelamatkan pasien DSS. Protokol yang dikeluarkan oleh World Health Organization (WHO) menganjurkan penggunaan cairan kristaloid pada awal penanganan yang kemudian dilanjutkan dengan pemberian koloid untuk pasien dengan syok rekuren atau refrakter. ${ }^{2,3}$ Meskipun angka kematian dapat diturunkan, namun penanganan antar negara, daerah, bahkan rumah sakit dalam satu daerah berlainan satu sama lain, terutama dalam pemilihan jenis cairan koloid. Di RS Sumber Waras Jakarta, untuk penanganan kasus DSS digunakan koloid yang berisi HES 6\% $40 \mathrm{kDa}$ dalam larutan ringer laktat. ${ }^{4}$ Sedangkan pusat pelayanan kesehatan lain umumnya menggunakan HES $200 \mathrm{kDa}$. Beberapa klinisi menggunakan gelatin dan dextran sebagai cairan koloid yang digunakan untuk resusitasi DSS.

Di Indonesia (Departemen Kesehatan), umumnya kriteria yang dipakai oleh klinisi untuk menentukan jenis cairan resusitasi koloid adalah berat molekul (BM) koloid. Hal ini didasari asumsi bahwa berat molekul yang lebih besar akan memberikan "efek sumbatan" (sealing effect) pada kapiler yang sedang mengalami kebocoran. Walaupun bukti nyata tentang dasar pemilihan ambang batas minimal ukuran molekul yang mampu memberi "sealing effect" masih sangat kurang, namun umumnya lebih banyak dipakai cairan koloid dengan BM rata-rata di atas $100 \mathrm{kDa}$. Kami berpendapat bahwa jika efek sumbatan yang terjadi lebih disebabkan efek mekanik, maka bentuk molekul penyumbat ini juga harus diperhatikan. Diketahui bahwa bentuk molekul koloid sangat bervariasi. Contohnya, koloid dengan berat molekul lebih kecil dan berbentuk cakram, mungkin saja mempunyai perpotongan dengan dinding pembuluh darah yang lebih besar dibandingkan dengan koloid yang lebih berat, namun berbentuk bulat. Dengan kata lain molekul dengan BM ringan namun berbentuk cakram (pipih) bisa jadi memiliki ukuran yang lebih besar (lebar) bila dibandingkan dengan molekul dengan BM besar namun berbentuk membulat. Jadi, pendapat bahwa koloid yang lebih berat dan lebih efisien dalam menyumbat kebocoran kapiler secara mekanik masih dipertanyakan. Tujuan penelitian untuk mengetahui dan membandingkan konstanta difusi (D) molekul dari berbagai macam koloid dengan BM berbeda untuk dapat menilai apakah ukuran molekul suatu koloid dapat ditentukan hanya dengan menilai BM.

\section{Metode}

Cairan koloid. Dipilih lima jenis cairan koloid dengan empat jenis BM yang berbeda dan sudah digunakan untuk resusitasi cairan dalam penanganan kasus DSS di berbagai rumah sakit di Indonesia, yaitu koloid 1 yaitu 3,5\% cross-linked polypeptides dari gelatin bovine yang didegradasi dengan BM rata-rata $30 \mathrm{kDa}$; koloid 2 yaitu $10 \%$ dextran dengan $\mathrm{BM}$ rata-rata $40 \mathrm{kDa}$; koloid 3 yaitu 6\% hydroxyl ethyl starch dengan BM rata-rata 40 $\mathrm{kDa}(\mathrm{HES} 40)$ dalam ringer laktat koloid 4 yaitu $6 \%$ HES 200 dengan $\mathrm{BM}$ rata-rata $200 \mathrm{kDa}$ dalam $\mathrm{NaCl}$; dan koloid 5: 6\% HES 200 dalam ringer laktat.

Konstanta difusi. Konstanta difusi merupakan suatu ukuran bagaimana partikel bergerak dalam cairan dan bergantung baik pada berat molekul maupun bentuk molekul. Semakin besar molekul dari cairan koloid dengan berat yang sama atau semakin berat molekul dari cairan koloid dengan bentuk yang sama cenderung bergerak lebih lambat akibat tarikan yang diberikan pada cairan, dan juga mempunyai konstanta difusi yang lebih kecil. Untuk molekul dengan bentuk dan berat yang sama, seperti protein globular, konstanta difusi sebanding dengan berat molekul. Oleh sebab itu, protein globular yang lebih berat akan berbentuk lebih besar dibandingkan dengan yang lebih ringan. Meskipun demikian, untuk polimer dan koloid dari bahan kimia dan fisika yang berbeda mungkin tidak memberikan hasil yang sama seperti di atas.

Dynamic light scattering (DLS). Pemeriksaan cairan koloid dilakukan di Center for Biomedical Engineering, Massachusetts Institute of Technology, Cambridge, Massachusetts. Dalam penelitian ini, kami menggunakan dynamic light scattering (DLS) untuk menilai konstanta difusi (D) dari berbagai molekul koloid yang digunakan dalam penanganan Dengue Shock Syndrome (DSS) dan menghubungkan hasilnya dengan berat molekul rata-rata koloid tersebut.

Pembacaan DLS dilakukan pada precision detector $P D D L S /$ batch dengan laser $680 \mathrm{~nm}$ yang dioperasikan 
pada $30 \mathrm{~mW}$. Scattered light (pendaran cahaya) dikumpulkan pada sudut $90^{\circ}$ dan fluktuasi intensitasnya diproses dengan menggunakan unit autocorrelator dalam instrumen tersebut. Data didapatkan dan kemudian ditampilkan menggunakan program precision deconcolve yang sesuai. Teori tentang DLS sudah dipelajari secara ekstensif dan dijelaskan secara singkat. Partikel-partikel dalam cairan akan memendarkan cahaya laser dengan intensitas tertentu yang bergantung pada posisi relatif partikel. Nilai intensitas akan berubah seiring pergerakan partikel-partikel yang saling mendekati atau menjauhi satu sama lain akibat pergerakan Brownian, beberapa waktu setelahnya, intensitas pendaran cahaya akan bervariasi. Variasi ini tergambar dalam fungsi korelasi intensitas, yang menunjukkan penurunan eksponensial untuk cairan yang homogen. Penurunan kurva dapat dihitung dengan rumus,

$$
\mathrm{g}_{\mathrm{E}}=\mathrm{e}^{-\mathrm{q}^{2} \mathrm{Dt}}(\text { rumus } 1)
$$

q adalah vektor pendaran dan merupakan konstanta instrumen. D merupakan koefisien difusi, dan $\mathrm{t}$ adalah waktu. Untuk cairan heterogen, penurunan kurva lebih kompleks dan mungkin akan dijelaskan oleh dua eksponensial atau lebih.

Untuk pembacaan DLS tertentu, cairan koloid $200 \mu \mathrm{l}$ dipindahkan melalui pipet dengan lambat ke dalam quartz micro-cuvette yang bersih. Waktu yang digunakan untuk autokorelasi sampel diatur sampai fungsi korelasinya mencapai nol kira-kira pada titik pertengahan aksis X. Untuk sampel yang menunjukkan populasi multipel, konstanta difusi untuk masingmasing populasi didapatkan secara manual dalam program.

\section{Hasil}

Dalam suatu cairan koloid, terdapat berbagai macam molekul dengan ukuran dan berat molekul berbeda. Kami menilai gambaran variasi molekul koloid dengan menggunakan koøefisien difusi seperti tertera pada Gambar 1, yaitu distribusi molekul pada koloid 5 (HES 6\% $200 \mathrm{kDa}$ ). Gambar 1 menunjukkan dua populasi, satu (populasi dominan, mayor) dengan konstanta difusi yang lebih besar kira-kira $6 \times 10^{-7}$ $\mathrm{cm}^{2} /$ detik dan yang kedua (populasi minor) berpusat

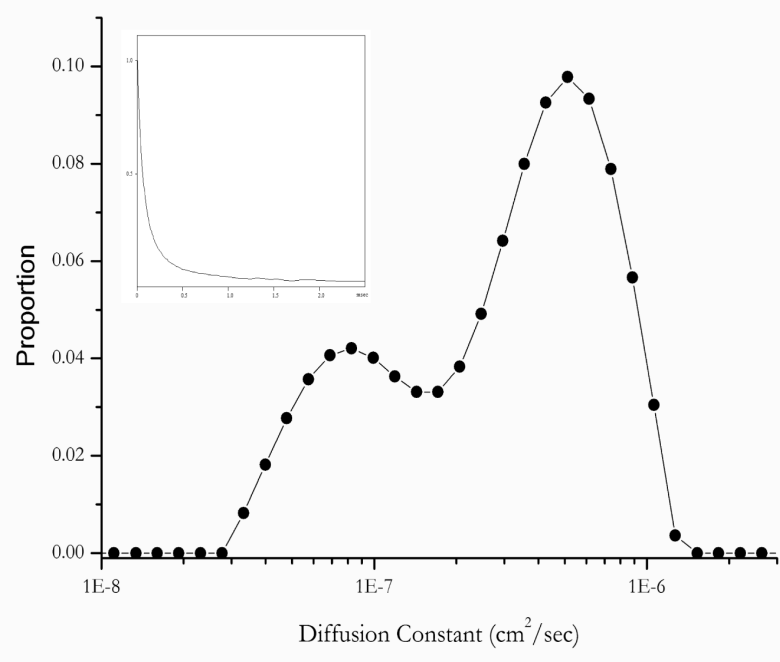

Gambar 1. Distribusi konstanta difusi berbagai molekul dalam suatu cairan koloid, (koloid 5). Kebanyakan molekul (populasi mayor) mempunyai konstanta difusi sebesar $6 \mathrm{x}$ $10^{-7-} \mathrm{cm}^{2} /$ detik. Populasi kedua (populasi minor) mempunyai konstanta difusi $1.4 \times 10^{-7} \mathrm{~cm}^{2} /$ detik.

pada $1,4 \times 10^{-7} \mathrm{~cm}^{2} /$ detik. Distribusi didapatkan dengan mencocokkan fungsi korelasi dengan satu eksponensial atau lebih yang memiliki konstanta difusi.

Konstanta difusi menggambarkan kecepatan sebuah partikel di dalam cairan bergerak karena adanya pergerakan Brownian, konstanta difusi yang lebih besar mengindikasikan bahwa molekul yang lebih kecil akan bergerak lebih cepat dalam cairan. Sebaliknya konstanta difusi yang kecil menandakan bahwa molekul yang lebih besar akan bergerak lebih lambat. Dalam partikel cairan yang murni, pengamatan terhadap bermacam-macam populasi dengan konstanta difusi yang berbeda-beda pada umumnya mengindikasikan adanya multimer atau agregrat yang lebih banyak.

Gambar 2 menunjukkan hubungan antara konstanta difusi dan berat molekul rata-rata. Dalam grafik ini juga di plot nilai untuk protein globular, yang mempunyai bentuk yang sama, yaitu sferis (membulat dengan simbol solid circle [O]). Nilai dari protein globular berada dalam satu garis lurus, yang mengindikasikan adanya hubungan langsung antara berat molekul dan konstanta difusi, sesuai dengan hasil untuk molekul yang berbentuk sama. Namun tampak molekul dalam cairan koloid tidak menunjukkan korelasi antara konstanta difusi dan berat molekul. Bahkan untuk koloid dengan berat 
Kiki M.K. Samsi dkk: Hubungan Berat Molekul dengan Ukuran Molekul Koloid pada DSS

Tabel 1. Kontansta difusi berbagai macam cairan koloid termasuk dalam populasi major dan populasi minor

\begin{tabular}{|c|c|c|c|}
\hline $\begin{array}{l}\text { Seluruh polulasi } \\
\text { molekul }\end{array}$ & $\begin{array}{c}\mathrm{BM} \\
(\mathrm{kDa})\end{array}$ & $\begin{array}{c}\text { Rata-rata D } \\
\left(\mathrm{cm}^{2} / \mathrm{sec}\right)\end{array}$ & $\begin{array}{l}\text { Stdev D } \\
\left(\mathrm{cm}^{2} / \mathrm{sec}\right)\end{array}$ \\
\hline Koloid 1 & 30 & $3.38 \times 10^{-9}$ & $1.11 \times 10^{-9}$ \\
\hline Koloid 2 & 40 & $6.40 \times 10^{-7}$ & $4.06 \times 10^{-8}$ \\
\hline Koloid 3 & 40 & $4.75 \times 10^{-7}$ & $2.39 \times 10^{-8}$ \\
\hline Koloid 4 & 200 & $3.79 \times 10^{-7}$ & $1.48 \times 10^{-8}$ \\
\hline Koloid 5 & 200 & $3.74 \times 10^{-7}$ & $1.33 \times 10^{-8}$ \\
\hline $\begin{array}{l}\text { Populasi Mayor } \\
\text { (dominan) }\end{array}$ & $\begin{array}{c}\mathrm{BM} \\
(\mathrm{kDa})\end{array}$ & $\begin{array}{c}\text { Rata-rata D } \\
\left(\mathrm{cm}^{2} / \mathrm{sec}\right)\end{array}$ & $\begin{array}{l}\text { Stdev D } \\
\left(\mathrm{cm}^{2} / \mathrm{sec}\right)\end{array}$ \\
\hline Koloid 1 & 30 & $9.85 \times 10^{-10}$ & $2.85 \times 10^{-10}$ \\
\hline Koloid 2 & 40 & $7.22 \times 10^{-7}$ & $3.74 \times 10^{-8}$ \\
\hline Koloid 3 & 40 & $7.50 \times 10^{-7}$ & $7.22 \times 10^{-8}$ \\
\hline Koloid 4 & 200 & $5.91 \times 10^{-7}$ & $4.94 \times 10^{-8}$ \\
\hline Koloid 5 & 200 & $5.79 \times 10^{-7}$ & $6.52 \times 10^{-8}$ \\
\hline Populasi Minor & $\begin{array}{c}\mathrm{BM} \\
(\mathrm{kDa})\end{array}$ & $\begin{array}{c}\text { Rata-rata D } \\
\left(\mathrm{cm}^{2} / \mathrm{sec}\right)\end{array}$ & $\begin{array}{l}\text { Std Dev D } \\
\left(\mathrm{cm}^{2} / \mathrm{sec}\right)\end{array}$ \\
\hline Koloid 1 & 30 & $6.97 \times 10^{-9}$ & $2.81 \times 10^{-9}$ \\
\hline Koloid 2 & 40 & $4.52 \times 10^{-8}$ & $2.25 \times 10^{-8}$ \\
\hline Koloid 3 & 40 & $1.88 \times 10^{-7}$ & $5.19 \times 10^{-8}$ \\
\hline Koloid 4 & 200 & $1.45 \times 10^{-7}$ & $5.32 \times 10^{-8}$ \\
\hline Koloid 5 & 200 & $1.45 \times 10^{-7}$ & $5.35 \times 10^{-8}$ \\
\hline
\end{tabular}

Tabel 1a. menggambarkan nilai konstanta difusi rata-rata berbagai cairan koloid yang berbeda; b) Nilai konstanta difusi rata-rata untuk populasi mayor dalam cairan koloid. c) Nilai konstanta difusi ratarata untuk populasi minor dalam cairan koloid. Dilakukan sepuluh kali pembacaan DLS untuk masing-masing koloid, dan kemudian hasilnya dirata-ratakan.

molekul rata-rata yang sama (koloid 2 dan koloid 3), konstanta difusi rata-rata dari keseluruhan partikel (populasi) memberikan hasil yang berbeda sampai lebih dari 35\%.

Pada Gambar 2, tertera bahwa koloid 1 mempunyai konstanta difusi yang rendah, jadi mempunyai bentuk yang jauh lebih besar dibandingkan dengan koloid lain. Hal ini berlawanan dengan berat molekul rata-ratanya yang paling rendah jika dibandingkan dengan semua koloid yang diteliti. Selain itu titik konstanta difusi koloid 1 berada paling jauh dari garis diagonal yang menghubungkan berbagai macam molekul speris dan ini berarti bahwa koloid 1 berbentuk paling pipih (seperti cakram) dibandingkan dengan molekul koloid lain.

Karena masing-masing cairan koloid terdiri dari minimal dua kelompok partikel (molecular

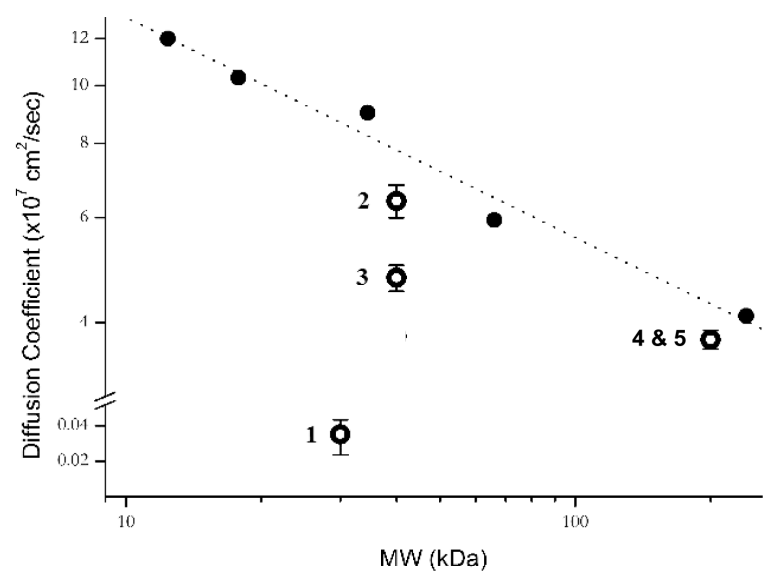

Gambar 2. Perbandingan berat molekul (dalam kDa) dengan koefisien difusi pada berbagai cairan koloid yang berbedabeda. Simbol solid circle [O] merupakan nilai untuk protein globular. Sedangkan simbol open circle [O] merupakan nilai rata-rata untuk koloid yang dipakai dalam penelitian ini. Angka-angka yang mewakili jenis cairan koloid sudah disebutkan di bagian materi dan metode.

population) seperti yang dilihat ada Gambar 1, kami kemudian menentukan rata-rata koefisien difusi untuk semua kelompok partikel pada masing-masing cairan. Pada hampir semua koloid, kelompok partikel yang dominan (major population) terdiri dari molekul dengan rata-rata konstanta difusi yang tertinggi, jadi merupakan kelompok partikel dengan ukuran terkecil. Sementara populasi minor (minor population) dengan konstanta difusi yang lebih rendah sepertinya terdiri dari agregrat-agregrat molekul. Satu-satunya koloid yang tidak mengikuti pola seperti ini adalah koloid 1.

Dengan memisahkan konstanta difusi berdasarkan populasi molekul yang berbeda kita dapat melihat bahwa pada populasi mayor, dua jenis cairan koloid yang diteliti, yaitu koloid 2 dan koloid 3 memiliki konstanta difusi yang mendekati (hampir sama dengan) protein globular dengan berat molekul yang sama (Gambar 3). Jadi kemungkinan struktur molekul koloid ini adalah globular (bulat)

Perbandingan konstanta difusi dan berat molekul populasi minor tertera pada Gambar 4. Populasi minor (minor population) koloid 1 mempunyai konstanta difusi yang lebih besar daripada populasi mayor, yang berarti ukurannya lebih kecil dan bergerak lebih cepat. Walaupun demikian, nilai ini 
Kiki M.K. Samsi dkk: Hubungan Berat Molekul dengan Ukuran Molekul Koloid pada DSS

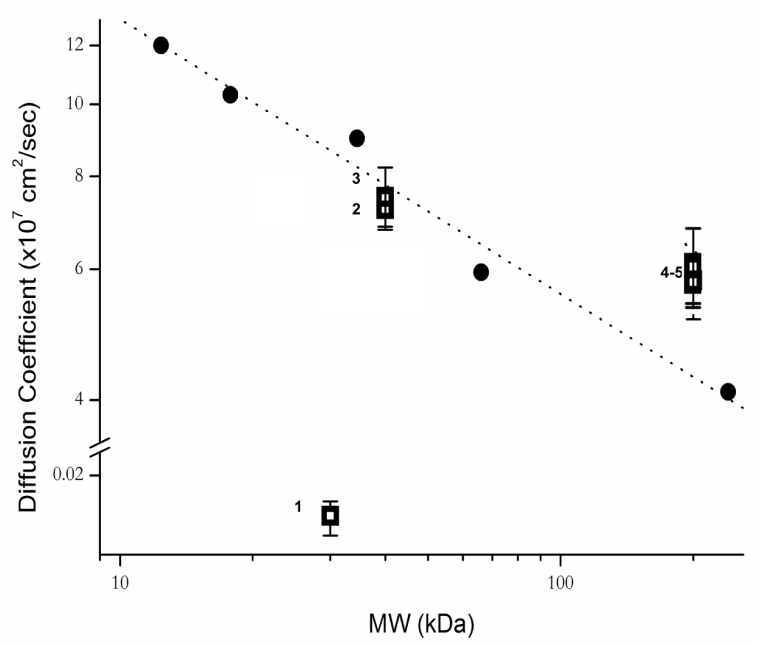

Gambar 3. Perbandingan berat molekul (dalam kDa) dengan koefisien difusi dari populasi mayor pada berbagai cairan koloid. Simbol solid circle [O] menandakan nilai untuk

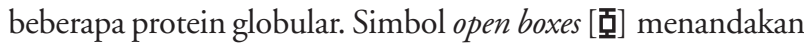
nilai untuk koloid yang dipakai dalam penelitian ini, yang merupakan hasil rata-rata dari 10 kali penilaian. Angka-angka yang mewakili jenis cairan koloid sudah disebutkan di bagian materi dan metode.

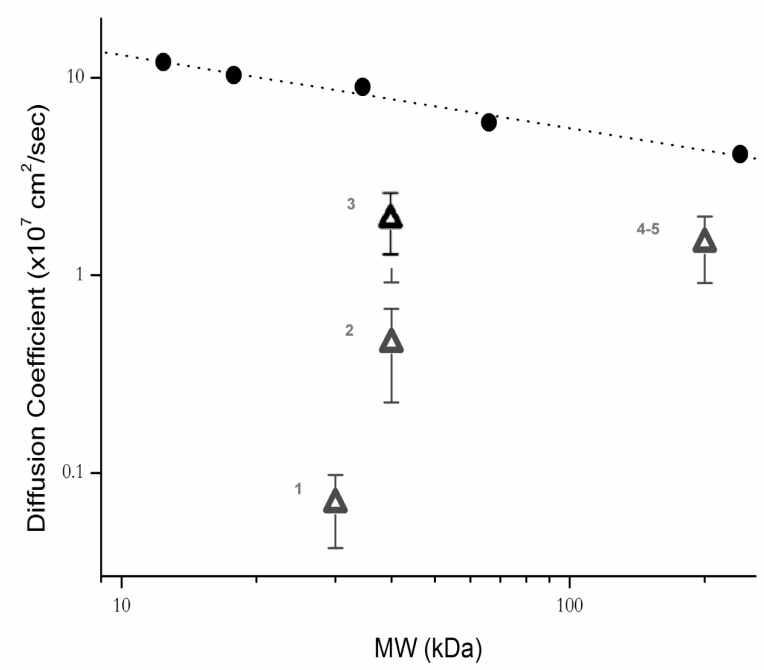

Gambar 4. Perbandingan berat molekul (dalam kDa) dengan koefisien difusi dari populasi minor pada berbagai cairan koloid. Simbol solid circle [O] menandakan nilai untuk beberapa protein globular yang sama dengan dengan Gambar 2 , hanya digunakan skala yang berbeda. Simbol open triangle [A] menandakan nilai untuk koloid yang dipakai dalam penelitian ini, yang merupakan hasil rata-rata dari $10 \mathrm{kali}$ penilaian. Angka-angka yang mewakili jenis cairan koloid sudah disebutkan di bagian materi dan metode.
Tabel 2. Perbandingan ukuran molekul pada seluruh populasi (rata-rata) berdasarkan konstanta difusi

\begin{tabular}{cr}
\hline $\begin{array}{c}\text { Perbandingan berat } \\
\text { molekul }\end{array}$ & $\begin{array}{c}\text { Perbandingan ukuran } \\
\text { berdasarkan perbedaan } \\
\text { konstanta difusi }\end{array}$ \\
\hline HES $200:$ HES 40 & $1,27: 1$ \\
Dextran $40:$ HES 40 & $1: 1,35$ \\
Gelatin $30:$ HES 200 & $100: 1$ \\
\hline
\end{tabular}

Tabel 3. Perbandingan ukuran molekul pada populasi mayor berdasarkan konstanta difusi

\begin{tabular}{|c|c|}
\hline $\begin{array}{c}\text { Perbandingan berat } \\
\text { molekul }\end{array}$ & $\begin{array}{l}\text { Perbandingan ukuran } \\
\text { berdasarkan perbedaan } \\
\text { konstanta difusi }\end{array}$ \\
\hline HES $200:$ HES 40 & $1,3: 1$ \\
\hline Dextran $40:$ HES 200 & $1: 1,2$ \\
\hline Dextran 40 : HES 40 & $1.04: 1$ \\
\hline Gelatin 30 : HES 40 & $733: 1$ \\
\hline Gelatin 30 : HES 200 & $600: 1$ \\
\hline
\end{tabular}

Tabel 4. Perbandingan ukuran molekul pada populasi minor berdasarkan konstanta difusi

\begin{tabular}{|c|c|}
\hline $\begin{array}{c}\text { Perbandingan berat } \\
\text { molekul }\end{array}$ & $\begin{array}{l}\text { Perbandingan ukuran } \\
\text { berdasarkan perbedaan } \\
\text { konstanta difusi }\end{array}$ \\
\hline HES 200 : HES 40 & $1,3: 1$ \\
\hline Dextran 40 : HES 200 & $3: 1$ \\
\hline Dextran 40 : HES 40 & $4,2: 1$ \\
\hline Gelatin 30 : HES 40 & $26: 1$ \\
\hline Gelatin $30:$ HES 200 & $22: 1$ \\
\hline
\end{tabular}

masih jauh lebih kecil dibandingkan dengan koloid lain yang mempunyai berat molekul $30 \mathrm{kDa}$, jika sifat lainnya dianggap konsisten. Nilai konstanta difusi rata-rata untuk koloid lain adalah $8-10 \times 10^{-7} \mathrm{~cm}^{2} /$ detik, atau kira-kira 100 kali lebih besar daripada nilai dari populasi minor koloid 1. Dengan kata lain ukuran molekul Koloid 1 lebih besar dari pada ukuran molekul koloid lainnya. Populasi minor koloid lain, seperti yang sudah disebutkan di atas, mempunyai konstanta difusi yang lebih kecil dibandingkan pada kelompok populasi mayor.

Perbedaan ukuran koloid dapat lebih mudah dengan membandingkan BM dengan difusi konstanta. Bila dibandingkan antara HES $6 \% 200 \mathrm{kDa}$ dengan HES 6\% $40 \mathrm{kDa}$, walaupun HES 6\% $200 \mathrm{kDa}$ lima kali lebih berat dari HES 6\% $40 \mathrm{kDa}$ berdasarkan perbedaan konstanta difusi namun ukuran HES 6\% 
$200 \mathrm{kDa}$ hanya 1,27 kali lebih besar (30\% lebih besar) (Tabel 2). Perbandingan dua koloid dengan BM yang sama menunjukkan adanya perbedaan perbandingan ukuran berdasarkan konstanta difusinya. Molekul HES 6\% $40 \mathrm{kDa}$ yang memiliki BM sama dengan Dextran $40 \mathrm{kDa}$, ternyata memiliki ukuran 1,35 kali lebih besar dari molekul Dextran. Perbedaan perbandingan ukuran molekul berdasarkan konstanta difusi tampak sangat bermakna bila dibandingkan antara HES 6\% 200 $\mathrm{kDa}$ dengan gelatin $30 \mathrm{kDa}$. Secara umum, walaupun HES 6\% $200 \mathrm{kDa}$ hampir tujuh kali lebih berat dari gelatin $30 \mathrm{kDa}$ namun gelatin $30 \mathrm{kDa}$ dengan bentuk molekul yang pipih (seperti cakram) memiliki ukuran 100x lebih besar (diameter lebih lebar) dari HES 6\% $200 \mathrm{kDa}$. Keadaan ini juga tampak pada Tabel 3 dan 4 apabila kita menilai pada kelompok populasi dominan (mayor) ataupun populasi minor.

\section{Pembahasan}

Para ahli sudah membuktikan bahwa protein plasma yang lebih kecil seperti albumin akan lebih mudah keluar dari celah vaskular dibandingkan dengan protein yang lebih besar seperti imunoglobulin G. Hal ini karena adanya "sieving effect" (efek saringan) yang tergantung dari berat molekul protein tersebut.7 Baik albumin maupun imunoglobulin G secara alamiah berbentuk globular (bulat), oleh karena itu semakin kecil berat molekul protein (albumin), konsanta difusinya akan lebih besar dan memiliki radius hidrodinamik yang lebih kecil jika dibandingkan dengan imunoglobulin G.

Kami meneliti konstanta difusi dari berbagai koloid menggunakan dynamic light scattering. Pada partikel dengan bentuk yang sama, seperti protein globular, memang terdapat korelasi antara konstanta difusi dan berat molekul, namun korelasi pada koloid tidak demikian sesederhana. Koloid yang paling besar dalam penelitian ini adalah koloid 4 dan 5, ternyata konstanta difusi kelompok tesebut tidak lebih kecil secara signifikan dibandingkan koloid lain, meskipun berat molekulnya jauh lebih besar. Selain itu, koloid 1 yang hanya memiliki berat molekul rata-rata 30 $\mathrm{kDa}$, ternyata memiliki bentuk yang besar. Hal ini mungkin disebabkan oleh perluasan/perpanjangan dan atau bentuk datar polimer. Satu hal yang harus diperhatikan adalah bahwa penelitian ini dilakukan pada suhu ruangan, sementara koloid akan bekerja pada suhu tubuh. Meskipun demikian, diharapkan dampak reaksi koloid dalam tubuh tidak akan jauh berbeda dengan hasil penelitian in-vitro.

Kesimpulan dari penelitian kami adalah berat molekul bukan merupakan petanda (marker) yang baik untuk memprediksi berapa besar ukuran molekul tersebut jika bentuknya tidak diketahui. Para klinisi yang menggunakan koloid untuk "menyumbat" kebocoran kapiler sebaiknya tidak hanya mempertimbangkan berat molekul dalam menilai efektivitas koloid. Jika efek sumbatan yang terjadi secara alamiah merupakan efek mekanik (atau dengan kata lain, molekul yang lebih besar dapat menyumbat lubang yang lebih besar) maka molekul koloid dengan bentuk yang lebih besar akan bekerja sama baiknya atau bahkan lebih baik dibandingkan dengan molekul yang lebih berat, namun bentuknya dipadatkan.

Untuk menentukan kriteria yang paling baik dalam memilih koloid yang tepat untuk resusitasi cairan pasien DSS, diperlukan penelitian yang komprehensif yang menilai faktor-faktor lain seperti karakteristik koloid in vivo (contohnya efek volume intra vaskular dan persistensi koloid dalam jaringan), mudahnya pemberian koloid, harga, dan juga efek samping. Sampai sejauh ini, belum ada penelitian yang menentukan jenis koloid mana yang lebih unggul untuk resusitasi pasien syok dengue. Penelitian yang ada selama ini hanya menampilkan data bahwa beberapa koloid mempunyai efek samping yang lebih besar. ${ }^{8}$

\section{Daftar Pustaka}

1. Gubler DJ. Dengue and dengue hemorrhagic fever. Clin microbiol rev 1998; 11:480-96.

2. World Health Organization. Technical guides for diagnosis, treatment, surveillance, prevention and control of dengue haemorrhagic fever. Geneva, 1975.

3. World Health Organization. Dengue haemorrhagic fever: diagnosis, treatment, prevention, and control. Geneva, 1997.

4. Samsi TK. Management of dengue shock syndrome: observations from one department. Journal of pediatrics, obstetrics \& gynecology, 2004; 31:184-92.

5. Vauthey S, Santoso S, Gong H, Watson N, Zhang S. Molecular self-assembly of surfactant-like peptides to form nanotubes and nanovesicles. Proc Natl Acad Sci U S A 2002; 99:5355-60.

6. Selivanova OM, Shiryaev VM, Tiktopulo EI, Potekhin 
SA, Spirin AS. Compact globular structure of thermus thermophilus ribosomal protein $s 1$ in solution: sedimentation and calorimetric study. J Biol Chem 2003;278:36311-4.

7. Wills BA, Oragui EE, Dung NM, Loan HT, Chau NV, Farrar JJ, dkk. Size and charge characteristics of the protein leak in dengue shock syndrome. J Infect Dis 2004;190:810-8.

8. Wills BA, Nguyen MD, Ha TL, Dong TH, Tran TN, Le TT, dkk. Comparison of three fluid solutions for resuscitation in dengue shock syndrome. $\mathrm{N}$ Engl J Med 2005;353:877-89. 